\title{
Modal Verbs of Obligation in Quotations and Political Discourse
}

\author{
Lusine Zakalashvili, Naira Avagyan \\ Yerevan State University
}

\begin{abstract}
This article discusses the modal verbs of obligation and their function in quotations and political discourse. The usage of modal verbs in speeches strengthens the impact on people, because they emphasize what people should, must, ought to and have to do. A political speech can enhance a politician's ratings or even secure a place in the history books.

Obligation expressed by modal verbs can be strong and weak. Must is chiefly used to express strong obligation. Should, ought to and had better can be used to express weak obligation. The study of modal verbs of obligation in quotations reveals some peculiarities in terms of gender differences.
\end{abstract}

Key words: modality, modal verbs, strong/weak obligation, quotation, written/oral mode, political speech, impact.

\section{Introduction}

Modality (from Latin modus - measure, method, shape) is a grammatical-semantic category which characterizes modus operandi or the speaker's attitude towards the action, his evaluation of the attitude towards objective reality. Modality concerns the factual status of information; it signals the relative actuality, validity or believability of the content of an expression. Modality includes the ways in which language is used to encode meanings such as degrees of certainty and commitment or alternatively vagueness and lack of commitment, personal beliefs versus generally accepted or taken for granted knowledge. Such language functions to express group membership, as speakers adopt positions, express agreement and disagreement with others, and make personal and social allegiances and contracts (Maynard 1990:86).

Modality can be expressed by different linguistic means. In actual speech all forms expressing modality work together to make the meaning clear. But in every case there is some leading form that expresses the main attitude. These forms fall into four categories: phonetic (intonation), grammatical (mood), lexicogrammatical (modal verbs), lexical (modal adverbs and phrases). But the most 
important of them appears to be the lexico-grammatical one, which includes modal verbs. Modal verbs are widely used in quotations which are either famous in their own right or utterances by (generally speaking) someone famous. Quotations can be maxims, aphorisms, striking fragments of poetry, humorous or impressive prose and remarks, coinages of new phrases or ideas, remarks at historical events, putdowns of others, famous last words or anything else which is worth repeating on its own, possibly with some comment on when, where, and who.

\section{Strong and Weak Obligation in Quotations}

Obligation expressed by modal verbs can be strong and weak. Must is chiefly used to express strong obligation. Should, ought to and had better can be used to express weak obligation. The study of modal verbs of obligation in quotations reveals some peculiarities in terms of gender differences. Thus, women are inclined to use modal verbs expressing weak obligation, whereas men are more likely to use modal verbs expressing strong obligation.

Sometimes I wonder if men and women really suit each other. Perhaps they should live next door and just visit now and then.

(Katharine Hepburn)

There must always remain something that is antagonistic to good.

To reach a port, we must sail - sail, not tie at anchor - sail, not drift.

(Franklin Roosevelt)

However, in certain cases the strong and weak obligation is determined not by the gender, but the human nature, character of the author. In quotations by strongwilled, powerful leaders, politicians should sounds as strong as must.

A Constitution should be short and obscure. (Napoleon Bonaparte)

To wear your heart on your sleeve isn't a very good plan; you should wear it inside, where it functions best. (Margaret Thatcher)

Germany should either be a world power or will not be at all. 
However beautiful the strategy, you should occasionally look at the results.

(Winston Churchill)

The study of quotations shows that there can be exceptions which are mainly connected with the individual and not just the gender or profession. In the examples above should sounds forceful, dogmatic and is equal to must, expressing strong obligation. Whereas, in the following examples must expresses weaker, milder obligation than in the quotes above.

We must convert our love for Christ into deeds. We must express Christian love in concrete, living ways.

(Mother Teresa)

The most beautiful things in the world cannot be seen or even touched, they must be felt with the heart.

(Helen Keller)

To be happy, we must not be too concerned with others.

(Albert Camus)

\section{The Impact of the Modals in Political Discourse}

The usage of modal verbs in political speeches has always had a great impact on people, because it emphasizes what people should, must, ought to and have to do. Many studies have investigated the relative persuasiveness of testimonials and factual information focused mainly on the message content. Testimonial is a statement in support of a particular truth, fact, or claim. The testimonial and pure informational message may be more or less effective, depending on both the recipient's involvement and also the mode by which the message is delivered (i.e., audio vs. written message).

An important factor that can moderate the effectiveness of testimonial versus fact-based informational messages is the delivery mode. The majority of studies that investigated persuasion, including those that compared testimonial stories and fact-based information dealt only with written forms of a message. However, the same message can be delivered through a multitude of modes. For example, it can be presented as a text (written mode) or as a recording (audio mode). The differences between the delivery mode can be observed through the reaction of public based on mostly the speeches by famous people, especially politicians. Formality of mode is shown in three ranks - low, medium and high. High 
politeness is used mostly in Obama's interviews in comparison to medium, and high politeness while Obama uses high modality with low rank of high politeness in his discourse. In this table, modals such as Dare, Might, Can, May and Could are used according to Obama's interviews to show low politeness, while Must, Ought to, Need and Has/Had to are used to show high politeness. Obama used lots of modal verbs in his speech to express his attitudes because they are easily understood and accepted by his interviewers and the audience.

\section{Low Politeness}

Can May

$36 \quad 30$
Medium Politeness

Should Must

$17 \quad 4$
High Politeness

Ought to Need Have to

214

28

Taking into consideration the fact that the two candidates of the 2012 USA presidential elections - Barak Obama and Mitt Romney were in a strong struggle, their speeches were written in a very persuasive way. During his Election Campaign Obama used mainly the modal verbs should, have to, while Romney used must which, in fact, didn't help him. Later the embassies of the USA in different countries made a social research where most of the people agreed that using strong words, like must, is somehow forcing people, whereas should is softer. So, Obama won the $51.1 \%$ and Romney $-47.2 \%$.

Here is a fragment from Obama's speech:

"So this weekend, as we look ahead to the next four years, we should absolutely take some time to truly enjoy these next few days. I mean, the last one was kind of fast. (Laughter) So we've all agreed that we're going to take some time to just breathe in and enjoy it. But let's also remember that this Inauguration is about more than all of the events that we will all enjoy this weekend. It's about more than swearing in a President. It's about more than we accomplish together over the next four years. It's also about the opportunities we have to make a real difference in people's lives."

(Applause)

Another quote from the same speech:

"The one thing that the American people should not have to wait and see is some sort of action. I just have to repeat - outside of Washington, nobody understands how it is that this seems to be a repeat pattern over and over again. Ordinary folks, they do their 
jobs. They meet deadlines. They sit down and they discuss things, and then things happen. If there are disagreements, they sort through the disagreements. The notion that our elected leadership can't do the same thing is mind-boggling to them. It needs to stop. So it has been. So it must be with this generation of Americans."

In his speech Mitt Romney used the modal verb must: it produced a negative effect on the audience, according to the election research committee of the USA:

"The nation, as you know, is at a critical point. At a time like this, we can't risk partisan bickering and political posturing. Our leaders must reach across the aisle to do the people's work."

"It is healthcare itself that must be brought under control if we are to keep our Medicare bills from overwhelming the next generation."

There is always a difference between the reactions of people who listen to the speech only or the ones who also watch the videos of speeches. Speeches can be understood in absolutely different ways on the radio and TV. Richard Nixon also understood this in 1952, when he gave the "Checkers" speech which was considered to be one of the most successful political speeches in history. The Checkers speech or Fund speech was an address made on September 23, 1952 by the Republican vice presidential candidate, California Senator Richard Nixon. His speech was seen or heard by about 60 million Americans, including the largest television audience to that time, and led to an outpouring of public support. A very important fact is that in the first of four debates, Nixon appeared pale, with a five o'clock shadow, in contrast to the photogenic Kennedy. Nixon's performance in the debate was perceived to be mediocre in the visual medium of television, though many people listening on the radio thought that Nixon had won. Nixon lost the election narrowly, with Kennedy ahead by only 120,000 votes ( 0.2 percent) in the popular vote. People who were listening on the radio gave their votes to Nixon, because his speech was persuasive. Here is a quote from that speech:

"Do you think that when I or any other Senator makes a political speech, has it printed, should charge the printing of that speech and the mailing of that speech to the taxpayers? Do you think, for example, when I or any other Senator makes a trip to his home state to make a purely 
political speech that the cost of that trip should be charged to the taxpayers? Do you think when a Senator makes political broadcasts or political television broadcasts, radio or television, that the expense of those broadcasts should be charged to the taxpayers?

Well, I know what your answer is. It is the same answer that audiences give me whenever I discuss this particular problem. The answer is, "no." The taxpayers shouldn't be required to finance items which are not official business but which are primarily political business."

The effect of must is strong and positive when used with the pronoun we, in parallel constructions and repetitions. Martin Luther King used mainly must in his speeches which had a strong effect; people were repeating his words, quoting them again and again. A famous speech Beyond Vietnam which was called A Time to Break Silence was delivered in Riverside Church in New York City on April 4, in 1967:

"And some of us who have already begun to break the silence of the night have found that the calling to speak is often a vocation of agony, but we must speak. We must speak with all the humility that is appropriate to our limited vision, but we must speak. And we must rejoice as well, for surely this is the first time in our nation's history that a significant number of its religious leaders have chosen to move beyond the prophesying of smooth patriotism to the high grounds of a firm dissent based upon the mandates of conscience and the reading of history. Perhaps a new spirit is rising among us. If it is, let us trace its movements and pray that our own inner being may be sensitive to its guidance, for we are deeply in need of a new way beyond the darkness that seems so close around us."

In the case of Martin Luther King we notice that the modal verb must is used more often than other modal verbs of obligation. Researchers have studied that Luther King was very often emotional (it was his nature), so he could use any word and it would have its power; as Wilbert Young said about Luther King: "His speech was powerful because he was speaking to what a whole race, even the country, was feeling". 
The same effect of the modal verb must may be observed in the speech of Abraham Lincoln, the $16^{\text {th }}$ President of the United States:

"But there is something that I must say to my people, who stand on the warm threshold which leads into the palace of justice: In the process of gaining our rightful place, we must not be guilty of wrongful deeds. Let us not seek to satisfy our thirst for freedom by drinking from the cup of bitterness and hatred. We must forever conduct our struggle on the high plane of dignity and discipline. We must not allow our creative protest to degenerate into physical violence. Again and again, we must rise to the majestic heights of meeting physical force with soul force."

The speeches of famous people become quotes during a very short period of time: people use them in their everyday lives. And one of the best speeches of all times is the speech by the American author, critic and scholar William Lyon Phelps which is remembered till now and has become very popular:

"A borrowed book is like a guest in the house; it must be treated with punctiliousness, with a certain considerate formality. You must see that it sustains no damage; it must not suffer while under your roof. You cannot leave it carelessly, you cannot mark it, you cannot turn down the pages, you cannot use it familiarly. And then, some day, although this is seldom done, you really ought to return it."

The modal verb of obligation dare is least frequently used in speech, but we have found some examples of dare used by the $35^{\text {th }}$ President of the United States, John F. Kennedy, serving from 1961 until his death in 1963. His winning speech was delivered on January 20, in 1961:

"We dare not forget today that we are the heirs of that first revolution. Let the word go forth from this time and place, to friend and foe alike, that the torch has been passed to a new generation of Americans - born in this century, tempered by war, disciplined by a hard and bitter peace, proud of our ancient heritage, and unwilling to witness or permit the slow undoing of those human rights to which this 
nation has always been committed, and to which we are committed today at home and around the world."

Other rare modal verbs of obligation shall, will and need are also met in Kennedy's winning speech. After that, the Americans used his words in journals, magazines, in their everyday lives and quoted it anywhere possible:

"Let every nation know, whether it wishes us well or ill, that we shall pay any price, bear any burden, meet any hardship, support any friend, oppose any foe, to assure the survival and the success of liberty. This much we pledge - and we shall more."

"All this will not be finished in the first one hundred days. Nor will it be finished in the first one thousand days; nor in the life of this Administration; nor even perhaps in our lifetime on this planet. But let us begin."

Barbara Pierce Bush, the wife of the $41^{\text {st }}$ President of the United States George $\mathrm{H}$. W. Bush, delivered speeches and presentations especially about her time spent in the closed-off China. One speech made by her had a great influence on people, especially the ones who were parents. In her exciting speech, she used the modal verb must, to make the impact of her speech stronger. The speech was in Commencement Address at Wellesley College on June 1, in 1990:

"Now maybe we should adjust faster; maybe we should adjust slower. But whatever the era twenty - whatever the era, whatever the times, one thing will never change: fathers and mothers, if you have children, they must come first. You must read to your children, and you must hug your children, and you must love your children. Your success as a family, our success as a society, depends not on what happens in the White House, but on what happens inside your house."

Anna Eleanor Roosevelt, the longest-serving First Lady of the United States, holding the post from 1933 to 1945 during her husband Franklin D. Roosevelt's four terms in office, made important declarations concerning human rights. Following her husband's death, Eleanor remained active in politics for the rest of her life. She pressed the US to join and support the United Nations and became one of its first delegates. 
She served as the first chair of the UN Commission on Human Rights, and oversaw the drafting of the Universal Declaration of Human Rights. Later she chaired the John F. Kennedy administration's Presidential Commission on the Status of Women. By her death, she was regarded as "one of the most esteemed women in the world" and "the object of almost universal respect". Eleanor used mainly should in her speech entitled The Struggle for Human Rights which was delivered in Paris, France, on September 28, in 1948. The multiple use of should expresses the character of Eleanor Roosevelt who could use should and it would have the same impact if she used must. So in her speech she wanted to seem milder and to emphasize her strength:

"We, in the democracies, believe in a kind of international respect and action which is reciprocal. We do not think others should treat us differently from the way they wish to be treated. It is interference in other countries that especially stirs up antagonism against the Soviet Government. If it wishes to feel secure in developing its economic and political theories within its territory, then it should grant to others that same security. We believe in the freedom of people to make their own mistakes. We do not interfere with them and they should not interfere with others."

\section{Conclusion}

It has been revealed that the choice of the use of a certain modal verb can have a decisive influence on the outcome of an event, as it did in the case of the US presidential elections of November 6, 2012. The study of modal verbs of obligation in quotations reveals some peculiarities in terms of gender differences. Thus, women are inclined to use modal verbs expressing weak obligation, whereas men are more likely to use modals of strong obligation. However, in certain cases the strong and weak obligation is determined not by the gender, but the human nature, character of the author. In quotations by strong-willed, powerful leaders, politicians should sounds stronger than must.

The use of the modal verbs of obligation in the oral mode of speech delivery is more influential than in the written mode. Words have always been powerful and decisive. The oral mode is even stronger than appearance. As a matter of fact, Richard Nixon got the majority of his votes from the people who were listening to the speech on the radio, because his pale face was not seen and only the strong voice and persuasive speech was heard. 
To sum up, each word we utter can have its effect, no matter positive or negative.

\section{References:}

1. Ballie, Sh. (2003) Lexico-Grammatical Means of Expressing Modality: London: Longman.

2. Maynard, S. (1990) Discourse Modality. Amsterdam: John Benjamins.

3. Palmer, F.R. (2001) Mood and Modality. $2^{\text {nd }}$ edition. Cambridge: CUP.

\section{Sources of Data:}

1. Famous Quotes. Available at: <www.philosophybasics.com/general quotes.html> [Accessed June 2015].

2. Greatest Speeches in History: Available at: <www.americanrhetoric.com /top100speechesall.html $>$ [Accessed May 2016].

3. Grothe, M. (2010) A World of Quotations that Say What They Mean and Mean What They Say. Cambridge: CUP.

4. Modal Verbs and Politeness Strategies in Political Discourse: Available at: $<$ https://mpra.ub.uni-muenchen.de/...MPRA_paper_45913.p> [Accessed September 2016].

5. Pell, J.A. (1995) Quotes for Living. Newbury Park, CA: Sage Press.

6. Philosophical Quotes: Thought-Provoking Sayings; Available at: $<$ www.quotegarden.com/philosophical.htm $>$ [Accessed April 2016].

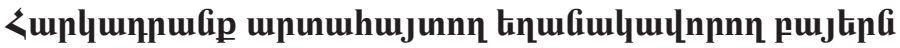

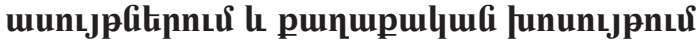

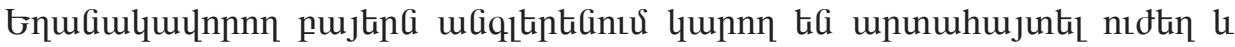

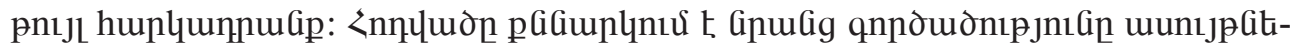

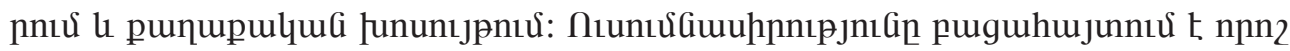

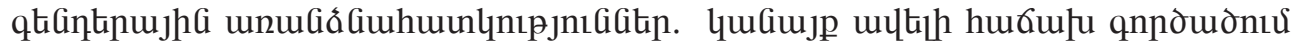

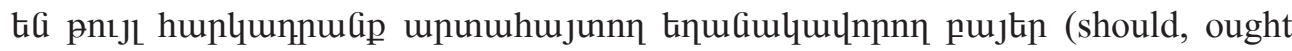

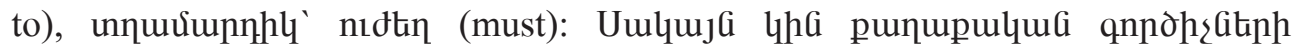

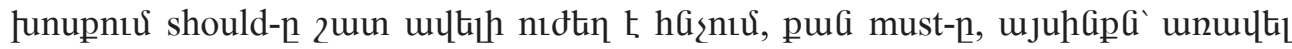

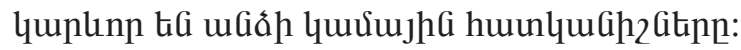

